\title{
Nutritional quality of the epicarp and mesocarp flours of baru fruits submitted to drying
}

\author{
Daiana V. Silva ${ }^{1}$, Daniel E. C. de Oliveira ${ }^{2}$, Osvaldo Resende ${ }^{3}$, Marco A. P. da Silva ${ }^{1} \&$ Keyla R. Barcelos ${ }^{1}$ \\ ${ }^{1}$ Instituto Federal de Educação, Ciência e Tecnologia Goiano/Campus Rio Verde. Rio Verde, GO. E-mail: daianadally@hotmail.com - ORCID: 0000-0001- \\ 9207-5875; marcotonyrv@yahoo.com.br - ORCID: 0000-0002-3875-1104; keylarezende@hotmail.com - ORCID: 0000-0002-0925-8150 \\ ${ }^{2}$ Instituto Federal de Educação, Ciência e Tecnologia Goiano/Campus Iporá. Iporá, GO. E-mail: oliveira.d.e.c@gmail.com (Corresponding author) - \\ ORCID: 0000-0002-3824-994X \\ ${ }^{3}$ Instituto Federal de Educação, Ciência e Tecnologia Goiano/Diretoria de Pesquisa e Pós-Graduação/Campus Rio Verde. Rio Verde, GO. E-mail: \\ osvresende@yahoo.com.br - ORCID: 0000-0001-5089-7846
}

\begin{abstract}
Baru (Dipteryx alata Vogel) is a native tree of the Cerrado. The drying and milling process can be an alternative for the use and conservation of baru fruits. The objective of this study was to evaluate the effect of drying on the nutritional characteristics of the epicarp + mesocarp flour of baru fruits. The fruits were collected in the municipality of Santa Helena de Goiás, Goiás, sanitized and submitted to drying in an oven with air circulation at temperatures of $40,60,80$ and $100^{\circ} \mathrm{C}$ until they had a constant mass. The analyses were performed in triplicate and the results evaluated by analysis of variance and Tukey test $(\mathrm{p} \leq 0.05)$. Flours produced from dehydrated fruits had a reduction in lipid content (treatments $100{ }^{\circ} \mathrm{C}$ ), energy value $(60$ and $\left.80^{\circ} \mathrm{C}\right), \mathrm{pH}$, soluble solids, apparent specific mass and carotenoids in relation to the control sample, and high values of acidity, antioxidant activity and total phenolics. FTIR analysis showed nutrient loss.
\end{abstract}

Key words: Dipteryx alata Vogel, antioxidant activity, phenolics, carotenoids

\section{Qualidade nutricional das farinhas do epicarpo e mesocarpo de frutos baru submetidos a secagem}

RESUMO: O baru (Dipteryx alata Vogel) é uma arbórea nativa do cerrado. O processo secagem e moagem pode ser uma alternativa para o aproveitamento e conservação dos frutos de baru. O objetivo deste estudo foi avaliar o efeito da secagem dos frutos sobre as características nutricionais das farinhas do epicarpo + mesocarpo de baru. Os frutos foram coletados na cidade de Santa Helena de Goiás, Goiás, higienizados e submetidos à secagem em estufa com circulação de ar nas temperaturas de 40, 60, 80 e $100^{\circ} \mathrm{C}$ até apresentarem massa constante. As análises foram realizadas em triplicata e os resultados avaliados por análise de variância e teste Tukey $(\mathrm{p} \leq 0,05)$. As farinhas produzidas de frutos desidratados apresentaram redução dos teores de lipídeos (tratamentos $100^{\circ} \mathrm{C}$ ), valor energético $\left(60\right.$ e $\left.80^{\circ} \mathrm{C}\right), \mathrm{pH}$, sólidos solúveis, massa especifica aparente e carotenoides em relação a amostra controle, e valores elevados de acidez, atividade antioxidante e fenólicos totais. A análise de FTIR demostrou perda de nutrientes.

Palavras-chave: Dipteryx alata Vogel, atividade antioxidante, fenólicos, carotenoides 


\section{INTRODUCTION}

The fruit of baru (Dipteryx alata Vogel) is about $4-5 \mathrm{~cm}$ in length, ovoid, with coriaceous epicarp, mesocarp of dark and spongy pulp and woody endocarp, has a seed that is about 2-2.5 cm long, ellipsoid and has a light brown color and shiny appearance.

Brazil has a great natural wealth, but this plant's wealth is not completely taken advantage of. In the country, there is a consumption of a large variety of native fruits, but there are few studies on the feasibility of introducing these foods in domestic markets (Oliveira \& Sigrist, 2008; Clerici \& CarvalhoSilva, 2011).

One of the alternatives to reduce post-harvest losses of fruits is the drying process, which reduces water activity and the chemical reactions that lead to deterioration of food. In addition, it prolongs shelf life, assists in the preservation, storage and reduction of costs in the transport of foods, which are lighter due to water loss (Suriya et al., 2016).

Due to the importance of the valorization of native species of the Cerrado and the dissemination of the potential of the baru fruit, this study was developed with the purpose of proposing a method of conservation of the fruit (dehydration), since baru is a seasonal fruit, by producing flours from the combination of two parts, the epicarp and mesocarp, since the commercial part of the fruit most valued and investigated is the almond, and evaluating the effect of the drying on the nutritional characteristics of the flour produced using baru epicarp and mesocarp (FEMB) from fruits not dried and fruits submitted to different drying temperatures (40, 60, 80 and $100^{\circ} \mathrm{C}$ ).

\section{MATERIAL AND Methods}

The fruits were collected in the municipality of Santa Helena de Goiás at $17^{\circ} 48^{\prime} \mathrm{S}, 50^{\circ} 35^{\prime} \mathrm{W}$ and altitude of $568 \mathrm{~m}$. The fruits were sent to the Laboratory of Post-Harvest of Vegetable Products of the Federal Institute of Goiás - Campus of Rio Verde. Five (1 kg) fruits (Dipteryx alata Vogel) were weighed, washed with a soft brush and distilled water and submitted to the sanitization process with $150 \mathrm{ppm}$ sodium hypochlorite for $15 \mathrm{~min}$. Four $1 \mathrm{~kg}$ baru portions were placed on perforated stainless steel trays and dried at $40,60,80,100{ }^{\circ} \mathrm{C}$ in an air circulation oven (Ethiktechnology), and a portion of fresh fruit was reserved and not dried. The samples were homogeneously overlapped on the surface of the tray, $5 \mathrm{~cm}$ thick, and subjected to drying until there was no further variation in the sample mass. After drying, a change was observed in the texture of the fruits, which were extremely rigid and furrowed, so it was necessary to immerse the fruits in water to remove the epicarp together with the mesocarp. The five portions of fruit samples were immersed in distilled water $\left(26^{\circ} \mathrm{C}\right)$ for $18 \mathrm{~h}$ to facilitate the process of removing the epicarp and mesocarp from the baru manually, with the aid of a stainless steel knife. The five fruit portions corresponding to the five treatments ( 1 treatment of fruits not dried and 4 treatments with fruits dried at temperatures of 40,60, 80 and $\left.100{ }^{\circ} \mathrm{C}\right)$. The epicarp and mesocarp contents extracted after immersion of the fruits in water were placed on trays and again dehydrated in an oven (Ethiktechnology) at $40^{\circ} \mathrm{C}$ for $24 \mathrm{~h}$ to produce the flour. The samples were ground (DIOGOMAQ electric mill) and sieved (1-mm-mesh stainless steel screen) and packed in polypropylene plastic bags, stored at $2{ }^{\circ} \mathrm{C}$ in a B.O.D. (Biochemical Oxygen Demand) incubator chamber until the analyses were carried out.

The products obtained were five flours from 5 treatments. The first treatment corresponds to the control flour of baru epicarp and mesocarp (FEMBCT), produced using fruits not dried. The remaining 4 treatments were obtained from flours produced using fruits dehydrated at $40,60,80$ and $100^{\circ} \mathrm{C}$, which were denominated: flour of epicarp and mesocarp of fruits dehydrated at $40{ }^{\circ} \mathrm{C}$ (FEMB40); flour of epicarp and mesocarp of fruits dehydrated at $60{ }^{\circ} \mathrm{C}$ (FEMB60); flour of epicarp and mesocarp of fruits dehydrated at $80{ }^{\circ} \mathrm{C}$ (FEMB80); flour of epicarp and mesocarp of fruits dehydrated at $100^{\circ} \mathrm{C}$ (FEMB100).

The moisture content was evaluated by gravimetric analysis in an oven at $130 \pm 1{ }^{\circ} \mathrm{C}$ according to the AACC method (44-15 A) (AACC, 2000). Ash content was analyzed according to AOAC method 923.03. The lipids were quantified using the Soxhlet technique (AOAC, 2000). The caloric value was estimated using the Atwater conversion factors of $4 \mathrm{kcal} \mathrm{g}^{-1}$ protein, $4 \mathrm{kcal} \mathrm{g}^{-1}$ carbohydrate, $9 \mathrm{kcal} \mathrm{g}^{-1}$ lipids. The carbohydrate content was calculated by the difference calculation method (Fernandes et al., 2010). To evaluate pH, soluble solids and acidity, a solution of flour and distilled water (1:10) was prepared. The $\mathrm{pH}$ was evaluated using a portable pH meter (Model MPA-210P) (AOAC, 2000). The acidity of the flour was determined by potentiometric titration. Soluble solids contents were determined using a digital refractometer (A. KRÜSS Optronic GmbH) (IAL, 2008). The apparent specific mass was calculated from the relationship between the mass and the direct reading of the volume occupied (Wani et al., 2015). The mineral content was determined by Atomic Emission Spectrometry (Atomic Absorption Spectrometer AAS-Vario 6, Analytik Jena) (Fernandes et al., 2010; Pineli et al., 2015). Phosphorus content was evaluated by colorimetry, and potassium by Flame Photometry (Teixeira et al., 2005).

The antioxidant activity was evaluated using the stable radical 2,2-diphenyl-1-picryl-hydrazyl (DPPH), and total phenolic contents were determined based on the colorimetric method of FolinCiocalteu, both methods described by Lemos et al. (2012). The antioxidant activity was also evaluated by the capture of the 2,2'-azinobis (3-ethylbenzothiazoline-6-sulfonic acid) radical $\left(\mathrm{ABTS}^{+}\right)$(Nenadis et al., 2004). The extracts used to evaluate antioxidant capacity and total phenolics were prepared using $70 \%$ acetone and 50\% methanol as described by Rufino et al. (2007).

The flavonoid contents were evaluated according to the method described by Dewanto et al. (2002). The evaluation of total carotenoids was determined using a $200 \mathrm{mg} \mathrm{L}^{-1} \mathrm{BHT}$ solution and the solvents acetone and ethanol (1:1) by volume of $1000 \mathrm{~mL}$, described by Talcott \& Howard (1999). The results were calculated using the coefficient of absorption of the carotenoid lutein $(\mathrm{A} 1 \% \mathrm{~cm}=2550)$, expressed in $\mu \mathrm{g}$ of total carotenoids in lutein equivalent per gram of the sample (Cisneros et al., 2004). 
The chemical composition of the samples was investigated using the Fourier-Transform Infrared Spectroscopy (FTIR) technique. Using a spectrometer (Varian Excalibur 3100 FT-IR) the spectra were recorded within the range of $500-4000 \mathrm{~cm}^{-1}$.

The results were submitted to analysis of variance and Tukey test $(\mathrm{p} \leq 0.05)$. The analyses were performed using SISVAR statistical software. The program Origin ${ }^{\circledR}$ presented the results of the infrared spectroscopy graphically.

\section{Results AND Discussion}

Table 1 shows the values of moisture content, ashes, lipids, proteins, total carbohydrates and energetic value of the epicarp and mesocarp flours of baru (Dipteryx alata Vogel).

The moisture contents of the epicarp and mesocarp flour of baru (FEMB) presented in Table 1 ranged from

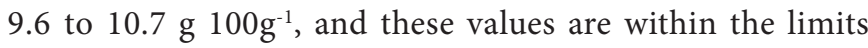
established by Resolution RDC n ${ }^{\circ} 263$ of ANVISA (National Health Surveillance Agency) (Brasil, 2005), which determines maximum levels of $15 \%$ (w.b.) of water content for foods called flours.

The samples FEMB40, FEMB60 and FEMB100 showed higher values of moisture content, and these results may have occurred due to the immersion of the samples in water to extract the epicarp and the mesocarp because both became rigid since the drying process of the fresh fruit altered its texture. The samples were immersed in distilled water for the same period $\left(18 \mathrm{~h}\right.$ at $\left.26^{\circ} \mathrm{C}\right)$, but fruits dried at temperatures of 40,60 and $100^{\circ} \mathrm{C}$ possibly absorbed water in different amounts, influencing the final water content of the flours.

As can be seen in Table 1, the production of flour from the epicarp and mesocarp of baru reduced the initial moisture content of the fresh fruit by $43 \%$ (d.b.). The ash contents of the samples were close to the results obtained by Alves et al. (2010),

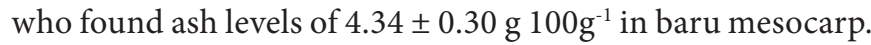

Regarding the lipid content of the FEMB, Table 1 shows that there was a reduction of the lipid content in the FEMB100 in relation to the control sample, FEMBCT.
The lipid contents of the baru flours (Table 1) were close to those reported in the study conducted by Carvalho et al. (2016), who reported lipid levels in fresh baru pulp equivalent to

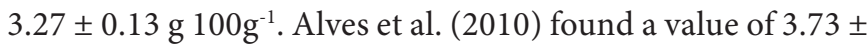

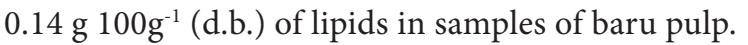

The protein content of FEMB samples was consistent with those found in the literature. Studies evaluating baru pulp

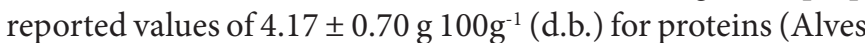
et al., 2010). Carvalho et al. (2016) reported levels of $3.68 \pm$

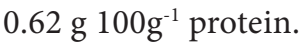

Regarding the energy value, FEMB60 (356.89 Kcal 100g-1) and FEMB100 (354.41 Kcal $\left.100 \mathrm{~g}^{-1}\right)$ showed differences ( $\left.\mathrm{p}>0.05\right)$

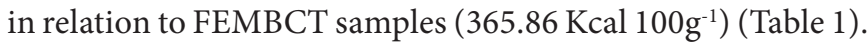

Table 2 shows $\mathrm{pH}$, acidity and soluble solids (SS) and apparent specific mass of the epicarp and mesocarp flours of baru (Dipteryx alata Vogel). In relation to the acid levels of baru flour, it is observed that the drying caused a significant increase in the samples FEMB40, FEMB60, FEMB80 and FEMB100, compared to the FEMBCT sample.

According to the legislation, the maximum acidity limit for common wheat flour is 3\%, and it does not establish an acidity parameter for fruit meal (ANVISA, 1978). The results of this study show that the baru flour was slightly acidic. The $\mathrm{pH}$ values of the samples FEMB40 (5.65), FEMB60 (5.66), FEMB80 (5.31), FEMB100 (5.32) were different from that of the FEMBCT sample (5.95). Decrease in $\mathrm{pH}$ and increase in the titratable acidity of the flours were observed with increasing drying temperature.

The FEMB40 (2.65 ${ }^{\circ}$ Brix), FEMB60 (2.59 ${ }^{\circ}$ Brix), FEMB80 (2.54 ${ }^{\circ}$ Brix), FEMB100 (2.57 ${ }^{\circ}$ Brix) showed low soluble solids content, and showed significant differences compared to the FEMBCT sample $\left(6.12^{\circ}\right.$ Brix). The immersion of the samples in water possibly caused the loss of soluble solids; however, all the five fruits that characterize the treatments (FEMBCT, FEMB40, FEMB60, FEMB80, FEMB100) were immersed in distilled water $\left(18 \mathrm{~h}\right.$ at $\left.26^{\circ} \mathrm{C}\right)$.

Foods may undergo Maillard reaction due to heat treatment. This reaction causes the degradation of sugars to acids and,

Table 1. Means of moisture content, ashes, lipids, proteins, carbohydrates and energetic value of baru (Dipteryx alata Vogel) flour

\begin{tabular}{|c|c|c|c|c|c|c|}
\hline Treatments & Moisture content & Ashes & $\begin{array}{l}\text { Lipids } \\
\left(\mathrm{q} 100 \mathrm{q}^{-1}\right)\end{array}$ & Proteins & Total carbohydrates & 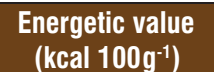 \\
\hline FEMBCT & $9.64 \pm 0.17 a$ & $4.44 \pm 0.16 a$ & $4.82 \pm 0.67 \mathrm{a}$ & $3.19 \pm 0.47 a$ & $77.43 \pm 0.40 a$ & $365.86 \pm 2.76 \mathrm{a}$ \\
\hline FEMB40 & $10.65 \pm 0.33 b$ & $3.43 \pm 0.24 \mathrm{a}$ & $4.83 \pm 0.06 a$ & $4.24 \pm 0.03 a$ & $76.57 \pm 0.30 a$ & $366.71 \pm 1.47 \mathrm{a}$ \\
\hline FEMB60 & $10.61 \pm 0.22 b$ & $4.87 \pm 0.25 \mathrm{a}$ & $4.23 \pm 0.26 a$ & $3.37 \pm 0.81 \mathrm{a}$ & $76.33 \pm 1.06 a$ & $356.89 \pm 1.07 b$ \\
\hline FEMB80 & $9.61 \pm 0.31 a$ & $4.46 \pm 1.01 \mathrm{a}$ & $3.86 \pm 0.39 a b$ & $3.81 \pm 0.40 \mathrm{a}$ & $77.79 \pm 1.69 a$ & $361.12 \pm 5.82 \mathrm{ab}$ \\
\hline FEMB100 & $10.37 \pm 0.04 b$ & $4.31 \pm 0.67 \mathrm{a}$ & $2.97 \pm 0.40 b$ & $2.99 \pm 0.38 \mathrm{a}$ & $78.93 \pm 1.40 \mathrm{a}$ & $354.41 \pm 1.94 b$ \\
\hline CV $(\%)$ & 2.33 & 13.17 & 9.87 & 13.89 & 1.40 & 0.86 \\
\hline
\end{tabular}

Means followed by the same letter in the column do not differ from each other, at the 0.05 level of significance, according to the Tukey test; Coefficient of variation (CV); Centesimal composition on dry basis

Table 2. Mean values and standard deviation of $\mathrm{pH}$, acidity, soluble solids and apparent specific mass of baru (Dipteryx alata Vogel) flour

\begin{tabular}{|c|c|c|c|c|}
\hline Treatments & $\begin{array}{c}\text { Acidity } \\
\text { (meq NaOH } 100 \mathrm{~g}^{-1} \text { ) }\end{array}$ & pH & $\begin{array}{l}\text { Soluble solids } \\
\text { ("Brix) }\end{array}$ & $\begin{array}{c}\text { Apparent specific mass } \\
\left(\mathrm{g} \mathrm{mL}^{-1}\right)\end{array}$ \\
\hline FEMBCT & $7.01 \pm 0.42 \mathrm{a}$ & $5.95 \pm 0.05 a$ & $6.12 \pm 0.11 \mathrm{a}$ & $0.74 \pm 0.01 \mathrm{a}$ \\
\hline FEMB40 & $7.54 \pm 0.58 a b$ & $5.65 \pm 0.03 b$ & $2.65 \pm 0.10 b$ & $0.60 \pm 0.01 d$ \\
\hline FEMB60 & $8.61 \pm 0.17 c$ & $5.66 \pm 0.03 b$ & $2.69 \pm 0.05 b$ & $0.66 \pm 0.01 \mathrm{c}$ \\
\hline FEMB80 & $8.06 \pm 0.25 b c$ & $5.31 \pm 0.04 c$ & $2.54 \pm 0.04 b$ & $0.69 \pm 0.00 b$ \\
\hline FEMB100 & $8.34 \pm 0.10 b c$ & $5.32 \pm 0.00 c$ & $2.57 \pm 0.04 b$ & $0.67 \pm 0.02 b c$ \\
\hline CV (\%) & 4.42 & 0.58 & 2.22 & 1.49 \\
\hline
\end{tabular}

Means followed by the same letter in the column do not differ from each other, at the 0.05 level of significance, according to the Tukey test; Coefficient of variation (CV); Rough results on dry basis 
since the pulp of baru has about $60 \%$ of carbohydrates, Maillard reaction may have occurred causing reduction of the content (Alves et al., 2010; Muzaffar \& Kumar, 2015).

The values of the specific mass of the samples FEMB40, FEMB60, FEMB80, FEMB100 (Table 2) significantly reduced with the increased drying temperature, and differed in relation to the FEMBCT sample. From the results it was observed that a greater amount of mass of the FEMBCT sample was required to occupy the same volume evaluated for the other flours.

Fazaeli et al. (2012) observed similar behavior, the authors reported that the increase in the temperature of the input air caused the reduction of the apparent specific mass of mulberry powders, obtained by the spray drying process.

The potassium, calcium, phosphorus, magnesium, iron, zinc, copper and manganese contents of baru (Dipteryx alata Vogel) flour are shown in Table 3.

Calcium content of FEMB40, FEMB80 and FEMB100, phosphorus contents of FEMB40, FEMB60 and FEMB80 and magnesium contents of FEMB40, FEMB60, FEMB80 and FEMB100 were significantly reduced compared to FEMBCT (Table 3). Among the macrominerals evaluated, potassium was present at a higher concentration in the epicarp and mesocarp flours of baru.

The levels of $\mathrm{Fe}, \mathrm{Zn}$ and $\mathrm{Cu}$ minerals present in FEMB did not show any variations among the evaluated treatments. The manganese contents of the FEMB40, FEMB60 and FEMB80 samples were significantly lower than the manganese content of the FEMBCT sample.

The antioxidant activities of the flours were evaluated using the $\mathrm{ABTS}^{\bullet+}$ and $\mathrm{DPPH} \cdot$ radicals, and the methods showed similar behavior in the FEMB samples, except the FEMB60 sample (Table 4).

Table 4 shows that the antioxidant activity of the FEMB samples obtained in the ABTS test showed a progressive increase in relation to the FEMBCT, and the results differed among all the treatments. In the results of the test using the DPPH radical, it was found that the samples FEMB40, FEMB80 and FEMB100 showed increased antioxidant activity and differed in relation to the FEMBCT samples.

The phenolic compound contents of the FEMB40, FEMB60, FEMB80, FEMB100 samples were significantly higher than those of the FEMBCT sample.

The FEMB100 sample had high content of phenolic compounds and antioxidant activity (Table 4 ). The contents of phenolics, ascorbic acid and carotenoids may exert influence on the antioxidant potential (Mendes et al., 2013).

In addition, the formation of melanoidins from the Maillard reaction may occur during the heating process. These substances have a variable degree of antioxidant activity, possibly leading to an increase in the antioxidant capacity of foods subjected to heat treatment at high temperatures (Lemos et al., 2012; Aydin \& Gocmen, 2015, Degirmencioglu et al., 2016).

Food processing may also lead to the formation of phenolic compounds due to availability of precursors of phenolic molecules or non-enzymatic interconversion between phenolic molecules (Aydin \& Gocmen, 2015).

Azeez et al. (2017), who evaluated the effect of tomato drying in a vacuum oven, observed that the contents of phenolic compounds and antioxidant activity increased in the treatments with higher temperature and shorter drying time.

Table 3. Mean values for potassium $(\mathrm{K})$, calcium $(\mathrm{Ca})$, phosphorus $(\mathrm{P})$, magnesium $(\mathrm{Mg})$, iron $(\mathrm{Fe})$, zinc $(\mathrm{Zn})$, copper $(\mathrm{Cu})$ and manganese $(\mathrm{Mn})$ of baru (Dipteryx alata Vogel) flour

\begin{tabular}{|c|c|c|c|c|}
\hline \multirow{2}{*}{ Treatments } & K & $\mathrm{Ca}$ & $\mathbf{P}$ & $\mathrm{Mg}$ \\
\hline & \multicolumn{4}{|c|}{$\left(\mathrm{mg} \mathrm{100g^{-1 } )}\right.$} \\
\hline FEMBCT & $1187.00 \pm 272 \mathrm{a}$ & $115.88 \pm 6.97 \mathrm{a}$ & $113.63 \pm 6.19 a$ & $80.00 \pm 7.5 \mathrm{a}$ \\
\hline FEMB40 & $1041.67 \pm 72.1 \mathrm{a}$ & $83.16 \pm 16.2 b c$ & $89.70 \pm 2.51 \mathrm{c}$ & $3.93 \pm 0.60 b$ \\
\hline FEMB60 & $1083.33 \pm 72.2 \mathrm{a}$ & $94.91 \pm 2.79 a b$ & $103.77 \pm 5.02 b$ & $10.52 \pm 1.60 b$ \\
\hline FEMB80 & $875.00 \pm 125 a$ & $87.89 \pm 7.11 b c$ & $93.32 \pm 0.69 c$ & $7.91 \pm 1.5 b$ \\
\hline FEMB100 & $1125.00 \pm 125 a$ & $67.37 \pm 11.58 c$ & $107.59 \pm 4.88 a b$ & $4.00 \pm 0.65 b$ \\
\hline \multirow[t]{3}{*}{ CV (\%) } & 14.33 & 11.17 & 2.73 & 16.50 \\
\hline & $\mathrm{Fe}$ & $\mathrm{Zn}$ & $\mathrm{Cu}$ & $\mathrm{Mn}$ \\
\hline & \multicolumn{4}{|c|}{$\left(\mathrm{mg} 100 \mathrm{~g}^{-1}\right)$} \\
\hline FEMBCT & $3.59 \pm 1.39 a$ & $8.75 \pm 1.70 \mathrm{a}$ & $3.38 \pm 0.39 a$ & $1.01 \pm 0.05 a$ \\
\hline FEMB40 & $2.96 \pm 0.31 \mathrm{a}$ & $8.03 \pm 0.15 a$ & $3.29 \pm 0.11 \mathrm{a}$ & $0.49 \pm 0.01 c$ \\
\hline FEMB60 & $3.12 \pm 0.53 a$ & $8.42 \pm 0.13 a$ & $3.12 \pm 0.12 \mathrm{a}$ & $0.64 \pm 0.14 b c$ \\
\hline FEMB80 & $3.27 \pm 0.37 \mathrm{a}$ & $8.33 \pm 0.33 a$ & $3.21 \pm 0.20 a$ & $0.77 \pm 0.11 b$ \\
\hline FEMB100 & $3.42 \pm 0.23 a$ & $8.18 \pm 0.23 a$ & $3.17 \pm 0.18 a$ & $0.78 \pm 0.02 a b$ \\
\hline CV $(\%)$ & 21.60 & 9.42 & 6.89 & 11.56 \\
\hline
\end{tabular}

Table 4. Mean values of trolox equivalent antioxidant capacity determined by two methods, using the DPPH and ABTS radicals, and total phenolic content of baru (Dipteryx alata Vogel) flour

\begin{tabular}{|c|c|c|c|c|c|}
\hline \multirow{3}{*}{ Treatments } & \multirow{3}{*}{$\begin{array}{c}\text { Total phenolics } \\
\text { (mg of gallic acid } 100 \mathrm{~g}^{-1} \text { ) }\end{array}$} & \multirow{3}{*}{$\begin{array}{l}\text { Total flavonoids } \\
\text { (mg of pyrocatechin } 100 \mathrm{~g}^{-1} \text { ) }\end{array}$} & \multirow{3}{*}{$\begin{array}{l}\text { Carotenoids } \\
\text { ( } \mu \mathrm{g} \mathrm{g}^{-1} \text { of lutein) }\end{array}$} & \multicolumn{2}{|c|}{ Antioxidant activity } \\
\hline & & & & ABTS test & DPPH test \\
\hline & & & & \multicolumn{2}{|c|}{$\left(\right.$ (umol trolox $\left.\mathrm{g}^{-1}\right)$} \\
\hline FEMBCT & $186.2 \pm 2.96 \mathrm{~d}$ & $6.70 \pm 0.38 a b$ & $10.7 \pm 0.22 \mathrm{a}$ & $13.82 \pm 0.33 \mathrm{e}$ & $9.53 \pm 0.75 d$ \\
\hline FEMB40 & $256.1 \pm 0.87 c$ & $6.90 \pm 0.40 a b$ & $5.52 \pm 0.18 b c$ & $16.57 \pm 0.81 d$ & $10.3 \pm 1.06 \mathrm{c}$ \\
\hline FEMB60 & $255.9 \pm 1.65 c$ & $5.53 \pm 0.40 b$ & $4.92 \pm 0.44 c$ & $20.04 \pm 0.73 c$ & $9.15 \pm 0.96 d$ \\
\hline FEMB80 & $376.1 \pm 0.43 b$ & $6.60 \pm 0.40 \mathrm{ab}$ & $4.52 \pm 0.31 c$ & $28.05 \pm 0.54 b$ & $11.4 \pm 0.98 b$ \\
\hline FEMB100 & $444.49 \pm 3.70 \mathrm{a}$ & $7.66 \pm 0.85 a$ & $6.06 \pm 0.09 b$ & $34.51 \pm 2.11 \mathrm{a}$ & $12.8 \pm 1.42 \mathrm{a}$ \\
\hline CV (\%) & 0.75 & 7.81 & 6.24 & 4.89 & 1.96 \\
\hline
\end{tabular}

Means followed by the same letter in the column do not differ from each other, at the 0.05 level of significance, according to the Tukey test; Coefficient of variation (CV); Rough results on dry basis 
In this study, a greater antioxidant activity was observed in the flour obtained from dehydrated fruits; therefore, the drying process of the baru fruits conferred advantages to it in relation to the antioxidant capacity even after the processing of the fruits in the form of flour. The presence of antioxidant substances benefits the conservation of the product, besides conferring health benefits since these substances help prevent degenerative and cardiovascular diseases (Mendes et al., 2013).

Table 4 shows that the sample FEMB60 (5.53 mg PE $\left.100 \mathrm{~g}^{-1}\right)$ had a lower flavonoid content, differing from the other treatments as well as the FEMB100 sample (7.66 mg PE $\left.100 \mathrm{~g}^{-1}\right)$. However, this sample had the highest value of flavonoids.

Azeez et al. (2017), evaluating the effect of tomato drying in a vacuum oven at temperatures of 50,60 and $70{ }^{\circ} \mathrm{C}$, observed that the levels of flavonoids and $\beta$-carotene decreased with increasing temperature and drying time.

Regarding the carotenoid content, it was observed that the reduction of carotenoids content occurred in the flours produced from fruits submitted to heat treatment. The samples FEMB60 and FEMB80 (Table 4) did not differ from each other in relation to the carotenoid content.

Mendes et al. (1990) observed similar behavior in their study, in which they reported that conventional convective drying $\left(60^{\circ} \mathrm{C}\right)$ resulted in a marked reduction in carotenoid contents. In this study this loss was attributed to drying temperature and the sensitivity of carotenoids to light and acidity.

The Fourier-transform infrared (FTIR) absorption spectra of the FEMB are shown in Figure 1. The intensity of the bands in the regions of 800 to $1200 \mathrm{~cm}^{-1}$ for FEMB40, FEMB60 and FEMB100 treatments is shown in Figure 1. Bands in the 800 to $1200 \mathrm{~cm}^{-1}$ region are characteristic of the stretching vibrations of C-C, C-OH and C-H bonds (Chen et al., 2017).

In Figure 1, 1047 and $1022 \mathrm{~cm}^{-1}$ bands are present, which are related to the amorphous and ordered structures of the starch (Chen et al., 2017). Carbohydrate characteristic bands in the region of 1400-900 $\mathrm{cm}^{-1}$ are also observed (Craig et al., 2015).

The presence of bands in the regions of 1636 and 1722-1759 $\mathrm{cm}^{-1}$ in the samples FEMB40, FEMB60, FEMB80 and FEMB100

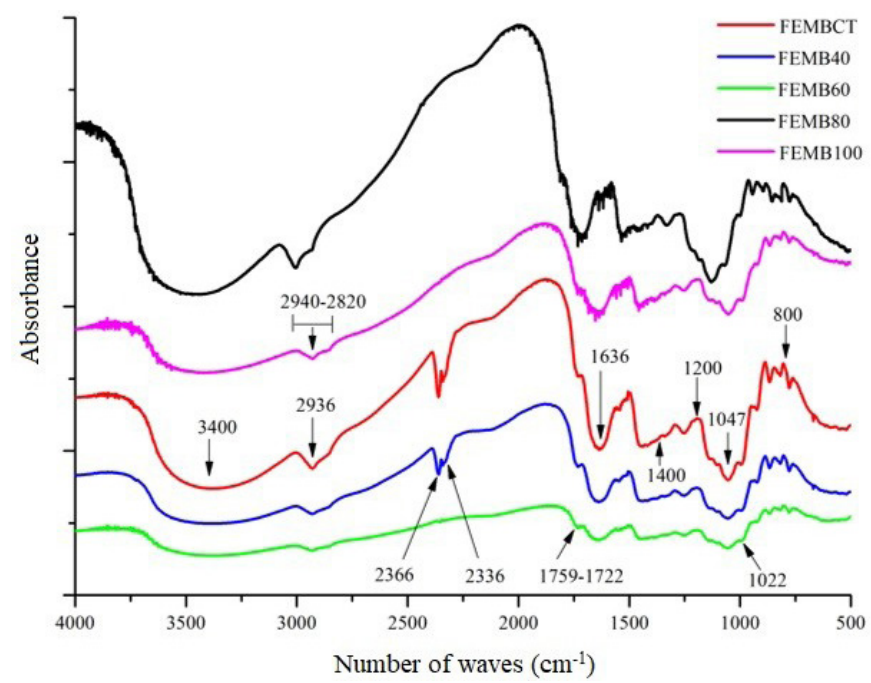

Figure 1. Fourier-transform infrared (FTIR) spectra absorption of the flours produced from the epicarp and mesocarp of baru (Dipteryx alata Vogel) are shown in Figure 1, and the intensity of these bands was reduced comparatively with the FEMBCT sample. Band in the $1636 \mathrm{~cm}^{-1}$ region can be attributed to the vibrations of the $\mathrm{H}-\mathrm{O}-\mathrm{H}$ molecule (Bashir et al., 2017). Bands in the region $1722-1759 \mathrm{~cm}^{-1}$ can be attributed to lipids (Craig et al., 2015).

It can be seen from Figure 1 that bands in the 2940$2820 \mathrm{~cm}^{-1}$ region, mainly in the $2936 \mathrm{~cm}^{-1}$ region of samples FEMB40, FEMB60 and FEMB100, were reduced in intensity according to the increase in drying temperature.

According to Craig et al. (2015), bands in the 2940$2820 \mathrm{~cm}^{-1}$ region are associated with the symmetrical and asymmetrical stretching of the $\mathrm{CH}$-binding bonds in the $\mathrm{CH}_{2}$ and $\mathrm{CH}_{3}$ groups. The presence of the asymmetrical and symmetrical elongation of $\mathrm{CH}_{2}$ is strongly related to the presence of lipids, as well as bands in the regions 2810-2848 and $2908-2920 \mathrm{~cm}^{-1}$.

The FEMBCT and FEMB40 samples showed bands in the $2366-2336 \mathrm{~cm}^{-1}$ region. The presence of asymmetrical primary amide occurs in the $3352 \mathrm{~cm}^{-1}$ region (Silverstein et al., 2005). The presence of bands of 3100 and $2000 \mathrm{~cm}^{-1}$ is associated with the presence of $\mathrm{N}-\mathrm{H}$ and $\mathrm{NH}_{3}$ groups.

\section{Conclusions}

1. Fruit drying resulted in the production of epicarp and mesocarp flour (FEMB) with reduced moisture content and $\mathrm{pH}$ and high acidity values, allowing fruit storage for prolonged periods.

2. The heat treatment resulted in the reduction of the lipid contents in the FEMB100 sample, of energy value in FEMB60 and FEMB80, and soluble solids, apparent specific mass, carotenoids in FEMB40, FEMB60, FEMB80 and FEMB100.

3. The samples FEMB40, FEMB60, FEMB80, FEMB100 showed a progressive increase in the content of phenolic compounds and antioxidant activity.

4. The results of the centesimal composition and FTIR analysis show that the epicarp and mesocarp flours of baru may be an alternative for the enrichment and formulations of foods. In addition, it has advantages in relation to the benefitcost ratio, since they were obtained by means of simple, lowcost procedures.

\section{ACKNowledgements}

The authors extend thanks to IF Goiano, CAPES, FAPEG, FINEP and $\mathrm{CNPq}$ for their financial support, which was indispensable to the execution of this study.

\section{Literature Cited}

AACC - American Association of Cereal Chemists. Approved methods of analysis. 10.ed. Saint Paul: AACC, 2000. sp.

Alves, A. M.; Mendonça, A. L. de; Caliari, M.; Santiago, R. de A. C. Avaliação química e física de componentes do baru (Dipteryx alata Vogel) para estudo da vida de prateleira. Pesquisa Agropecuária Tropical, v.40, p.266-273, 2010.

ANVISA - Agência Nacional da Vigilância Sanitária. Farinhas. Brasília: Diário Oficial da União, 1978. Disponível em: <http:// www.anvisa.gov.br/anvisalegis/resol/12_78_farinhas.htm $>$. Acesso em: Jan. 2018. 
AOAC - Association of Official Analytical Chemists. Official methods of analysis of the association of official analytical chemists. 17.ed. Washington: AOAC, 2000. 1018p.

Aydin, E.; Gocmen, D. The influences of drying method and metabisulfite pre-treatment on the color, functional properties and phenolic acids contents and bioaccessibility of pumpkin flour. Food Science and Technology, v.60, p.385-392, 2015.

Azeez, L.; Adebisi, S. A.; Oyedeji, A. O.; Adetoro, R. O.; Tijani, K. O. Bioactive compounds contents, drying kinetics and mathematical modelling of tomato slices influenced by drying temperatures and time. Journal of the Saudi Society of Agricultural Sciences, v.17, p.1-7, 2017. https://doi.org/10.1016/j.jssas.2017.03.002

Bashir, K.; Swer, T. L.; Prakash, K. S.; Aggarwal, M. Physico-chemical and functional properties of gamma irradiated whole wheat flour and starch. Food Science and Technology, v.76, p.131-139, 2017.

Brasil. Instrução normativa No 08, de 02 de junho de 2005. Aprova o regulamento técnico de identidade e qualidade da farinha de trigo. Brasília: Diário Oficial da União, 2005. 91p. Seção 1

Carvalho, A. A.; Barbosa, E. S. P.; Siqueira, K. F. Aproveitamento de resíduos de processamento de castanha de baru para desenvolvimento de gelado comestível. Revista Processos Químicos, v.10, p.287-293, 2016.

Chen, X.; Li, X.; Mao, X.; Huang, H.; Wang, T.; Qu, Z.; Miao, J.; Gao, W. Effects of drying processes on starch-related physicochemical properties, bioactive components and antioxidant properties of yam flours. Food Chemistry, v.224, p.224-232, 2017. https://doi. org/10.1016/j.foodchem.2016.12.028

Cisneros, M.; Benavides, J.; Brenes, C. H.; Rito-Palomares, M. Recovery in aqueous two-phase systems of lutein produced by the green microalga Chlorella protothecoides. Journal of Chromatography B, v.807, p.105-110, 2004. https://doi. org/10.1016/j.jchromb.2004.01.009

Clerici, M. T. P. S.; Carvalho-Silva, L. B. Nutritional bioactive compounds and technological aspects of minor fruits grown in Brazil. Food Research International, v.44, p.1658-1670, 2011. https://doi.org/10.1016/j.foodres.2011.04.020

Craig, A. P.; Franca, A. S.; Oliveira, L. S.; Irudayaraj, J.; Ileleji, K. Fourier transform infrared spectroscopy and near infrared spectroscopy for the quantification of defects in roasted coffees. Talanta, v.134, p.79-386, 2015. https://doi.org/10.1016/j.talanta.2014.11.038

Degirmencioglu, N.; Gürbüz, O.; Herken, E. N.; Yildiz, A. Y. The impact of drying techniques on phenolic compound, total phenolic content and antioxidant capacity of oat flour tarhana. Food Chemistry, v.194, p.587-594, 2016. https://doi.org/10.1016/j. foodchem.2015.08.065

Dewanto, V.; Wu, X.; Adom, K. K.; Liu, A. R. H. Thermal processing enhances the nutritional value of tomatoes by increasing total antioxidant activity. Journal of Agricultural and Food Chemistry, v.50, p.3010-3014, 2002. https://doi.org/10.1021/jf0115589

Fazaeli, M.; Emam-Djomeh, Z.; Ashtari, A. K.; Omid, M. Effect of spray drying conditions and feed composition on the physical properties of black mulberry juice poder. Food and Bioproducts Processing, v.90, p.667-675, 2012. https://doi.org/10.1016/j.fbp.2012.04.006

Fernandes, D. C.; Freitas, J. B.; Czeder, L. P.; Naves, M. M. V. Nutritional composition and protein value of the baru (Dipteryx alata Vog.) almond from the Brazilian Savanna. Journal of the Science of Food and Agriculture, v.90, p.1650-1655, 2010. https:// doi.org/10.1002/jsfa.3997
IAL - Instituto Adolfo Lutz. Métodos físico-químicos para análise de alimentos. São Paulo: Instituto Adolfo Lutz, 2008. 1020p.

Lemos, M. R. B.; Siqueira, E. M. de A.; Arruda, S. F.; Zambiazi, R. C. The effect of roasting on the phenolic compounds and antioxidant potential of baru nuts (Dipteryx alata Vogel). Food Research International, v.48, p.592-597, 2012. https://doi.org/10.1016/j. foodres.2012.05.027

Mendes, G. R. L.; Freitas, C. H. de; Scaglioni, P. T.; Schmidt, C. G.; Furlong, E. B. Condições para desidratação osmótica de laranjas e as propriedades funcionais do produto. Revista Brasileira de Engenharia Agrícola e Ambiental, v.17, p.1210-1216, 2013. https:// doi.org/10.1590/S1415-43662013001100012

Muzaffar, K.; Kumar, P. Moisture sorption isotherms and storage study of spray dried tamarind pulp poder. Powder Technology, v.291, p.322-327, 2016. https://doi.org/10.1016/j.powtec.2015.12.046

Nenadis, N.; Wang, L. F.; Tsimidou, M.; Zhang, H. Y. Estimation of scavenging activity of phenolic compounds ising the ABTS $\left({ }^{*}+\right)$ assay. Journal of Agricultural and Food Chemistry, v.52, p.46694674, 2004. https://doi.org/10.1021/jf0400056

Oliveira, M. I. B.; Sigrist, M. R. Fenologia reprodutiva, polinização e reprodução de Dipteryx alata Vogel (Leguminosae-Papilionoideae) em Mato Grosso do Sul, Brasil. Revista Brasileira de Botânica, v.31, p.195-207, 2008. https://doi.org/10.1590/S010084042008000200002

Pineli, L. de L. de O.; Carvalho, M. V. de; Aguiar, L. A. de; Oliveira, G. T. de; Celestino, S. M. C.; Botelho, R. B. A.; Chiarello, M. D. Use of baru (Brazilian almond) waste from physical extraction of oil to produce flour and cookies. LWT -Food Science and Technology, v.60, p.50-55, 2015. https://doi.org/10.1016/j.lwt.2014.09.035

Rufino, M. S. M.; Alves, R. E.; Brito, E. S. de; Morais, S. M. de; Sampaio, C. de G.; Pérez-Jiménez, J.; Calixto-Saura, F. D. Determinação da atividade antioxidante total em frutas pela captura do radical livre DPPH. Fortaleza: Embrapa Agroindústria Tropical, 2007. 4p. Comunicado Técnico, 127

Silverstein, R. M.; Webster, F. X.; Kiemle, D. J. Identificação espectrométrica de compostos orgânicos. 7.ed. Rio de Janeiro: LTC, 2005. 506p.

Suriya, M.; Baranwal, G.; Bashir, M.; Reddy, C. K.; Haripriya, S. Influence of blanching and drying methods on molecular structure and functional properties of elephant foot yam (Amorphophallus paeoniifolius) flour. Food Science and Technology, v.68, p.235243, 2016.

Talcott, S. T.; Howard, L. R. Phenolic autoxidation is responsible for color degradation in processed carrot puree. Journal of Agricultural and Food Chemistry, v.47, p.2109-2115, 1999. https:// doi.org/10.1021/jf981134n

Teixeira, I. R.; Borém, A.; Araújo, G. A. de A.; Andrade, M. J. B. de. Teores de nutrientes e qualidade fisiológica de sementes de feijão em resposta à adubação foliar com manganês e zinco. Bragantia, v.64, p.83-88, 2005. https://doi.org/10.1590/S000687052005000100009

Wani, I. A.; Wani, A. A.; Gania, A.; Muzzaffar, S.; Gul, M. K.; Masoodi, F. A.; Wani, T. A. Effect of gamma-irradiation on physico-chemical and functional properties of arrowhead (Sagittaria sagittifolia L.) tuber flour. Food Bioscience, v.11, p.23-32, 2015. https://doi. org/10.1016/j.fbio.2015.04.003 